\title{
PLURALISME HUKUM PERKAWINAN DI TAPANULI SELATAN
}

\author{
Ikhwanuddin Harahap \\ Institut Agama Islam Negeri Padangsidimpuan \\ Jl. HT. Nurdin Sihitang Km. 4.5 Padangsidimpuan, Sumatera Utara, 22733 \\ e-mail: ikhwanuddin_harahap@yahoo.com
}

\begin{abstract}
Abstrak: Pluralisme hukum merupakan fenomena universal yang dialami oleh semua bangsa. Ia mencakup berbagai aspek kehidupan manusia seperti hukum, politik, dan ekonomi. Pluralisme hukum adalah keniscayaan yang harus diterima. Dalam bingkai pluralisme hukum, masyarakat dihadapkan pada berbagai pilihan hukum, yaitu hukum adat, hukum agama dan hukum negara, tidak terkecuali masyarakat Tapanuli Selatan Provinsi Sumatera Utara. Masyarakat di daerah ini juga mengalami pluralisme hukum dalam bidang perkawinan. Paling tidak, tiga sistem hukum bisa menjadi pilihan mereka atau bahkan dengan melakukan kombinasi antar hukum yang ada. Penelitian ini dilakukan dengan pendekatan kualitatif fenomenologis untuk melihat bentuk relasi antar hukum yang hidup di tengah-tengah masyarakat Tapanuli Selatan. Temuan penelitian ini mendeskripsikan bahwa pada level tertentu, secara umum, keragaman hukum perkawinan merupakan sebuah harmonisasi, di mana masyarakat menggunakan dua sistem hukum bahkan lebih pada saat yang bersamaan. Namun ada kalanya pada situasi tertentu, keragaman hukum ini berubah menjadi "ketegangan".
\end{abstract}

\begin{abstract}
Legal Pluralism on Marriage in South Tapanuli. Legal pluralism is an universal phenomenon experienced by all nations. He covers various aspects of human life, such as law, politics and economics. Legal pluralism is a necessity that must be accepted. In the framework of legal pluralism, people are faced with a variety of legal choices, namely customary law, religious law and state law. No exception is the South Tapanuli community of North Sumatra Province. Communities in this area also experience legal pluralism in the field of marriage. At least, there are three legal systems that can be choosed or by combining existing laws. This research was conducted with a phenomenological qualitative approach to see the form of interlegal relations that lived in the midst of the community of South Tapanuli. The findings of this study describe that at a certain level, in general, the diversity of marital law is a harmonization, in which people use two legal systems even more at the same time. But sometimes in certain situations, the legal pluralism turns into "tension".
\end{abstract}

Kata Kunci: pluralisme hukum, perkawinan, Mandailing, Tapanuli Selatan 


\section{Pendahuluan}

Fenomena pluralisme hukum sangat universal. ${ }^{1}$ Masyarakat global hidup dalam lingkaran keragaman hukum. Mereka dihadapkan pada berbagai pilihan hukum yang eksis di tengah-tengah mereka. Dengan demikian, mereka dapat memilih salah satu hukum dan meninggalkan hukum lainnya sesuai dengan keinginannya.

Pluralisme hukum terjadi pada semua bangsa. Dalam bahasa Brian Z. Tamahana, legal pluralism is everywhere, ${ }^{2}$ di mana pluralisme hukum terjadi pada semua tingkat mulai dari tingkat lokal maupun global, tingkat pedesaan maupun perkotaan. Tidak hanya menyangkut tempat, pluralisme hukum juga menyentuh berbagai aspek kehidupan sosial dan hukum dalam masyarakat. Pendeknya, pluralisme hukum menyentuh semua wilayah dan segala aspek. ${ }^{3}$ Gejala pluralisme hukum ini juga terjadi di Indonesia.

Masyarakat Indonesia adalah masyarakat yang hidup dalam keragaman atau pluralisme hukum. Mereka tunduk pada tiga hukum sekaligus yaitu hukum adat, hukum agama dan hukum nasional. Ketundukan terhadap hukum adat merupakan konsekuensi logis dari fakta bahwa hukum pertama yang mereka kenal adalah hukum adat; jauh sebelum hukum agama dan hukum nasional ada. Sementara ketundukan kepada hukum agama adalah sebuah keniscayaan, sebab hukum agama mengandung doktrin, nilai transendental dan holistik yang menuntut kepatuhan secara totalitas guna memperoleh jaminan hidup yang baik di kehidupan selanjutnya (yaumul akhir/life after death). Sedangkan ketundukan kepada hukum nasional adalah sebuah keharusan sebagai konsekuensi dari sistem negara Indonesia yang berdasarkan pada hukum (rechtstaat).

Pluralisme hukum pada prinsipnya berbicara tentang eksistensi berbagai hukum yang ada dalam suatu komunitas sekaligus menjelaskan pola relasi antar hukum tersebut.

${ }^{1}$ Lando Kirchmair, "Descriptive vs. Prescriptive Global Legal Pluralism: A Gentle Reminder of David Hume's is-ought Divide", dalam The Journal of Legal Pluralism and Unofficial Law, Vol. 51, 2019, h. 48-71. Ia menyebutnya dengan global legal pluralism.

${ }^{2}$ Brian Z. Tamahana, "Understanding Legal Pluralism: Past to Present, Local to Global," dalam Sydney Law Review, Vol. 30, 2007, h. 375

${ }^{3}$ Untuk merepresentasikan fenomena pluralisme hukum pada berbagai aspek di beberapa negara lihat Arskal Salim, "Contemporary Islamic Law in Indonesia: Sharia and Legal Pluralism," dalam The Aga Khan University, Vol. 6, 2015; Livia Holden \& Azam Chaudhary, "Daughters' Inheritance, Legal Pluralism, and Governance in Pakistan," dalam The Journal of Legal Pluralism and Unofficial Law, Vol. 45, 2013, h. 104-123; Tommaso Sbriccoli, "Legal Pluralism in Discourse: Justice, Politics and Marginality in Rural Rajasthan, India," dalam The Journal of Legal Pluralism and Unofficial Law, Vol. 45, 2013, h. 143-164; Rustamjon Urinboyev \& Mans Svensson, "Living Law, Legal Pluralism and Corruption in Post-Soviet Uzbekistan," dalam The Journal of Legal Pluralism and Unofficial Law, Vol. 45, 2013, h. 372-390; Birgit Brauchler, "The Revival Dilemma: Reflections on Human Rights, Self-Determination and Legal Pluralism in Eastern Indonesia," dalam The Journal of Legal Pluralism and Unofficial Law, Vol. 42, 2010, h. 1-42; Mhd. Syahnan, Modernization of Islamic Law of Contract (Jakarta: Badan Litbang \& Diklat Departemen Agama RI, 2009); Mhd. Syahnan, Contemporary Islamic Legal Discourse (Medan: IAIN Press, 2010). 
Untuk konteks Indonesia misalnya, pluralisme hukum dipahami sebagai keragaman hukum yaitu hukum adat, hukum agama dan hukum positif. Sementara representasi paling populer dari pola relasi antar hukum yang ada adalah persentuhan Islam dan budaya ${ }^{4}$ atau hukum Islam, hukum adat dan hukum negara. ${ }^{5}$

Fakta bahwa pluralisme hukum terjadi pada semua masyarakat, suku dan bangsa sungguh tidak dapat dipungkiri. Hanya saja, sejauh mana kekuatan dan kelemahan pluralisme hukum tersebut sangat sulit diukur. Pada satu sisi, pluralisme hukum memberikan kepastian hukum, namun di sisi lain pluralisme hukum melahirkan kebimbangan dalam masyarakat.

Fenomena pluralisme hukum sebagaimana diuraikan di atas juga dialami oleh masyarakat Tapanuli Selatan. Masyarakat Tapanuli Selatan adalah komunitas yang hidup di daerah Tapanuli bagian Selatan Provinsi Sumatera Utara, yaitu Kota Padangsidimpuan, Kabupaten Tapanuli Selatan, Kabupaten Padang Lawas, Kabupaten Padang Lawas Utara dan Kabupaten Mandailing Natal. Kelima daerah ini adalah pemekaran dari Kabupaten Tapanuli Selatan.

Masyarakat Tapanuli Selatan dikenal sebagai masyarakat yang kental dengan kehidupan adat (maradat). Artinya, mereka tunduk dan menjalankan adat dalam kehidupannya. Di sisi lain, masyarakat Tapanuli Selatan juga dikenal dengan masyarakat religius yang taat dalam menjalankan syariat agama, yaitu agama Islam sebagai agama mayoritas penduduk di daerah ini. Selain itu, mereka juga dikenal sebagai warga negara yang baik, yang tunduk dan patuh terhadap aturan negara. Dengan demikian, mereka patuh dan hidup dalam tiga sistem hukum, yaitu adat, Islam dan negara.

Pluralisme hukum pada masyarakat Tapanuli Selatan ini menyentuh berbagai aspek termasuk perkawinan. Ketika seseorang menikah, ia dihadapkan pada ketiga sistem hukum di atas. Dengan demikian ada berbagai pilihan hukum; apakah ia menikah secara adat atau tidak, sesuai ajaran Islam atau tidak, sejalan dengan hukum perkawinan Indonesia atau tidak. Dengan demikian, konsekuensi logisnya adalah apabila ia memilih salah satu hukum dan mengabaikan hukum yang lain maka akan berdampak legalitas perkawinan tersebut baik legalitas dari perspektif adat, Islam maupun negara. Pilihan hukum lain adalah memilih lebih dari satu hukum yang ada dalam artian tunduk dan menjalankan hukum adat, Islam dan negara secara bersamaan.

${ }^{4}$ Pola relasi yang ada diklasifikasikan pada empat bentuk, yaitu sinkretik, akulturatif, kolaboratif dan legitimasi. Lihat Deni Miharja, "Persentuhan Agama Islam dengan Kebudayaan Asli Indonesia," dalam MIQOT: Jurnal Ilmu-Ilmu Keislaman, Vol. XXXVIII, No.1, 2014, h. 202206; Murdan, "Pluralisme Hukum (adat dan Islam) di Indonesia," dalam Mahkama: Jurnal Kajian Hukum Islam, Vol. 1 No. 1, 2016, h. 48-60.

${ }^{5}$ Franz Benda-Beckmannn \& Keebet von Benda-Beckmannn, "Changing One is Changing All: Dynamics in the Adat-Islam-State Triangle," dalam The Journal of Legal Pluralism and Unofficial Law, Vol. 38, 2006, h. 239-270. Beckmann mendeskripsikan relasi adat, Islam dan Negara dalam kehidupan masyarakat Minangkabau, Sumatera Barat. Lihat juga M. Zaki, "Arah Legislasi Hukum Islam di Indonesia dalam Perspektif Interaksi Agama dan Negara," dalam MIQOT: Jurnal Ilmu-Ilmu Keislaman, Vol XLII, No.2, 2015, h. 63-77. 
Pluralisme hukum perkawinan di Tapanuli Selatan ini menyisakan berbagai masalah yang menarik untuk dikaji. Sebab, pluralisme hukum tidak hanya sekadar menyuguhkan keragaman hukum yang ada di masyarakat, akan tetapi ia juga berbicara mengenai relasi antar hukum. Perspektif Griffiths digunakan dalam menganalisis permasalahan ini dengan pandangannya tentang weak legal pluralism dan strong legal pluralism. ${ }^{6}$

Berdasarkan uraian di atas, studi ini ingin menguraikan bentuk pluralisme hukum yang terjadi pada masyarakat Tapanuli Selatan dalam bidang perkawinan. Fokus studi ini adalah pada penemuan bentuk relasi antar hukum adat, nasional dan Islam dalam bidang perkawinan di Tapanuli Selatan. Penelitian ini merupakan penelitian kualitatif fenomenologis. Dengan demikian, penelitian ini dilakukan dengan mengamati fenomena perkawinan di Tapanuli Selatan. Sumber data dalam penelitian ini adalah tokoh adat, tokoh agama, dan pegawai Kantor Urusan Agama. Data diperoleh melalui observasi dan wawancara. Untuk menjamin keabsahan data dilakukan teknik triangulasi. Data yang diperoleh dianalisis dengan teknis content analysis.

\section{Kerangka Teoritis}

\section{Pluralisme Hukum: Overview}

Istilah pluralisme hukum (legal pluralism) pertama kali digunakan oleh pakar sosiologi hukum bernama Gurvitch (1935). ${ }^{7}$ Menurutnya, "Legal pluralism referred to a situation in which people could choose from among more than one co-existing set of rules." Merujuk pada pernyataan tersebut, pluralisme hukum dapat berarti suatu situasi di mana orang dapat memilih antara lebih dari satu aturan yang ada. Sementara Griffiths mengemukakan bahwa pluralisme hukum mengacu pada lebih dari satu tatanan hukum dalam suatu arena sosial. ${ }^{8}$ Definisi senada juga dikemukakan oleh Sally Engle Merry. ${ }^{9}$ Berbagai definisi dari para ahli tentang pluralisme hukum pada umumnya mengarah pada satu pengertian bahwa pluralisme hukum merupakan keragaman hukum yang hidup di tengah-tengah masyarakat terutama hukum adat atau kebiasaan, hukum agama dan hukum negara.

Wacana pluralisme hukum lahir sebagai kritikan terhadap sentralisme dan positivisme hukum. Sentralisme hukum berpandangan bahwa satu-satunya institusi yang memiliki kewenangan dan berperan menciptakan keteraturan sosial termasuk hukum adalah negara melalui hukum yang dibentuk dan ditetapkan oleh negara. Pluralisme hukum memberikan

${ }^{6}$ John Griffiths, "What is Legal Pluralism?," dalam The Journal of Legal Pluralism and Unofficial Law, Vol. 18, 1986, h. 9.

${ }^{7}$ Keebet von Benda-Beckmann dan Bertram Turner, "Legal Pluralism, Social Theory, and The State", dalam The Journal of Legal Pluralism and Unofficial Law, Vol. 50, No. 3, 2018, h. 262.

${ }^{8}$ John Griffiths, "What is Legal Pluralism," h. 9.

${ }^{9}$ Sally Engle Merry, "Legal Pluralism," dalam Law and Society Review, Vol. 221, 1988, h. 869-896. 
pandangan baru bahwa hukum yang diterapkan kepada rakyat tidaklah un sich hukum negara, akan tetapi ada kekuatan hukum lain yang hidup di tengah-tengah masyarakat seperti living law. ${ }^{10}$ Bagi Ehrlich, pencetus living law, perkembangan hukum sesungguhnya berpusat pada masyarakat itu sendiri, bukan pada pembentukan hukum oleh negara, putusan hakim, ataupun pada pengembangan ilmu hukum. Ehrlich memandang bahwa masyarakat sendirilah yang merupakan sumber utama hukum. Dengan kata lain hukum tidak dapat dilepaskan dari masyarakatnya. Dengan dasar tersebut, Ehrlich mengatakan bahwa hukum yang hidup (the living law) adalah hukum yang mendominasi kehidupan itu sendiri meskipun belum dimasukkan ke dalam proposisi hukum. Selain living law ada kekuatan hukum lain, yaitu hukum adat (customary law) dan hukum agama.

Sebagai sebuah kajian, pluralisme hukum mengalami perkembangan dan pergeseran interpretasi. Awalnya pluralisme hukum mendeskripsikan bagaimana berbagai sistem hukum bekerja dengan baik dalam masyarakat. Masyarakat dengan leluasa memilih di antara beberapa hukum yang ada. Dalam perkembangan selanjutnya, pemikiran mengenai pluralisme hukum mengalami pergeseran. Di mana pluralisme hukum tidak hanya menjelaskan adanya keanekaragaman hukum di lapangan sosial tertentu, akan tetapi mengelaborasi makna di balik keragaman hukum tersebut. Tidak hanya sampai di sana, pluralisme hukum juga menggambarkan proses saling mempengaruhi antar hukum sebagai hasil dari interaksi di antara mereka, serta bagaimana kondisi sistem-sistem hukum yang ada ketika berada dalam suatu lapangan sosial tertentu, atau bahkan lebih dari sekadar saling berinterkasi dan saling mempengaruhi, yaitu adanya kompetisi di antara sistem hukum. ${ }^{11}$

Diskursus pluralisme hukum semakin menggeliat setelah Griffiths mengemukakan konsep weak legal pluralism dan strong legal pluralism. Menurutnya, pluralisme hukum disebut sebagai weak legal pluralism atau pluralisme hukum yang lemah adalah pada saat negara mengakui kehadiran dan keberadaan sistem hukum lain di luar hukum negara, akan tetapi sistem-sistem hukum non negara tersebut tunduk keberlakuannya di bawah hukum negara. Sedangkan disebut strong legal pluralism atau pluralisme hukum yang kuat adalah pada saat negara mengakui keberadaan hukum non negara dan sistem hukum tersebut mempunyai kapasitas keberlakuan yang sama dengan hukum negara. ${ }^{12}$ Dengan demikian dalam konteks ini pluralisme hukum bersifat complementary. ${ }^{13}$

${ }^{10}$ Eugen Ehrlich, Fundamental Principles of The Sociology of Law, Walter L. Moll trans., 1936, h. 137.

${ }^{11}$ Martha-Marie Kleinhans dan Roderick A Macdonald, "What is a Critical Legal Pluralism," dalam Canadian Journal of Law and Society, Vol. 12 No.2, 1997, h. 25-46; Pembahasan dalam perspektif Hukum Islam, lihat Mhd. Syahnan, Hukum Islam dalam Bingkai Transdisipliner (Medan: Perdana Publishing, 2018).

${ }^{12}$ John Griffiths, "What is Legal Pluralism?" h. 6-8.

${ }^{13}$ Geoffrey Swenson, "Legal Pluralism in Theory and Practice," dalam International Studies Review, Vol. 20, 2018, h. 342. 
Dalam perkembangannya, pluralisme hukum tidak sepi dari kritikan. Oleh sebagian kalangan seperti Benda-Beckmann memandang bahwa pluralisme hukum tidak dipandang sebagai teori, namun ia hanya sebagai sensitizing concept. Ia menyebutkan bahwa ...Legal pluralism in the anthropological sense therefore is a sensitizing concept for situations in which people draw upon several legal systems, irrespective of their status within the state legal system. ${ }^{14}$

Terlepas dari perdebatan dan kritikan mengenai pluralisme hukum, hal yang pasti adalah bahwa pluralisme hukum adalah fakta empiris yang tidak bisa dielakkan dalam kehidupan masyarakat.

\section{Perkawinan di Tapanuli Selatan}

Perkawinan pada masyarakat Tapanuli Selatan memiliki arti yang sangat penting. Ada sembilan makna yang terkandung dalam perkawinan. Pertama, Haroan boru ${ }^{15}$ (kedatangan pengantin perempuan) ke dalam keluarga laki-laki membawa "tuah". Dikatakan membawa tuah karena si perempuan telah menyatukan dua keluarga besar yaitu keluarga suami dan keluarga isteri. Kedua, penabalan kampung (bonabulu) kepada sang boru. Dalam pandangan adat, kampung/bonabulu seorang laki-laki sama dengan kampung/bonabulu orang tuanya, tetapi anak perempuan baru memiliki kampung/bonabulu setelah ia dikawinkan. Kampung/bonabulunya mengikuti kampung/bonabulu suaminya. Ketiga, peresmian melepas masa gadis dan masa pemuda bagi kedua penganten yang disaksikan oleh orang banyak. Status mereka sudah menjadi suami dan isteri. Keempat, penabalan menjadi dewasa kepada kedua pengantin. Dalam adat Tapanuli Selatan seseorang disebut dewasa ialah kalau ia sudah berumah tangga. Meskipun seseorang sudah berusia 60 tahun, tidak disebut dewasa jika ia belum kawin. Kelima, serah terima tanggungjawab. Mulai saat perkawinan tersebut mereka telah menjadi anggota masyarakat dan berkewajiban mengunjungi siluluton ${ }^{16}$ dan siriaon ${ }^{17}$ anggota masyarakat lainnya. Keenam, memberikan nama kepada suami isteri, di mana nama dipakai adalah nama yang biasa digunakan dalam kelompok suami. Ketujuh, memberi bekal untuk menguatkan tondi ${ }^{18}$ dan badan dalam memulai hidup baru, yaitu hidup berumah tangga tersebut. Untuk menguatkan badan adalah makanan-makanan yang ada dalam pangupa. ${ }^{19}$ Kedelapan, pernyataan dari semua keluarga pihak pengantin

\footnotetext{
${ }^{14}$ Keebet von Benda-Beckmann dan Bertram Turner, "Legal Pluralism, Social Theory, and The State", h. 264.

${ }^{15}$ Boru dalam bahasa Tapanuli Selatan bermakna pengantin perempuan.

${ }^{16}$ Siluluton adalah tradisi atau adat yang bersifat duka cita, seperti peristiwa kematian.

${ }^{17}$ Siriaon adalah tradisi atau adat yang bersifat suka cita, seperti peristiwa perkawinan, masuk rumah baru, kelahiran anak.

${ }^{18}$ Tondi adalah benda abstrak yang mengisi dan menuntun badan kasar dan jiwa. Dalam pandangan masyarakat Tapanuli Selatan, manusia terdiri dari 3 unsur yaitu badan, jiwa (roh) dan tondi. L.P. Hasibuan, Pangupa: Buku Nenek Moyang Masyarakat Tapanuli Selatan (Medan: Mitraco, 1991), h. 25.

${ }^{19}$ Pangupa sajian yang diletakkan di depan pengantin. Bahan-bahan pangupa itu adalah
} 
laki-laki yang disaksikan raja-raja adat bahwa mereka berbesar hati menerima boru menjadi anggota dalam kelompok mereka. Kesembilan, pernyataan dari raja-raja adat yang hadir bahwa ikatan kekeluargaan telah terjalin dengan sempurna dengan adanya perkawinan tersebut. Fungsi adat telah berjalan dengan sebaik-baiknya. ${ }^{20}$

Setiap komunitas masyarakat memiliki bentuk-bentuk perkawinan ideal. Pada masyarakat Tapanuli Selatan ada beberapa perkawinan yang dianggap paling baik. Pertama, Borutulang, yaitu menikahi anak perempuan dari saudara laki-laki ibu, atau dikenal dengan istilah perkawinan manyunduti. Kedua, berlainan marga, asalkan tidak ada hubungan keluarga sebelumnya sebagai penghalang. Ketiga, satu faham dalam kepercayaan, karena dahulu paham sangat erat hubungannya dengan dengan adat. Keempat, satu derajat dalam tingkat kedudukan adat. Kelima, satu bentuk pengertian dan pelaksanaan adat. ${ }^{21}$

Selain perkawinan ideal, pada masyarakat Tapanuli Selatan dikenal perkawinan terlarang. Pertama, tidak boleh mengawini perempuan yang semarga. Seorang laki-laki dilarang mengawini wanita yang semarga dengannya. Misalnya laki-laki bermarga Nasution tidak boleh menikahi perempuan bermarga Nasution. Apabila terjadi perkawinan dua orang yang memiliki marga yang sama disebut perkawinan sumbang. Risikonya, mereka diberi sanksi adat, berupa pengisolasian atau pengucilan dan denda adat berupa kewajiban menyembelih kerbau atau kambing. Kedua, tidak boleh mengawini anak perempuan dari saudara perempuan bapak. Dalam partuturon saudara perempuan bapak disebut bou. Perkawinan ini disebut perkawinan rompak tutur. ${ }^{22}$ Oleh karena itu mangawini anak perempuan dari bou adalah dilarang. Jika terjadi perkawinan demikian, maka harus merombak adat (mangarompak tutur) yang berarti juga sebagaimana halnya merombak rumah. Caranya adalah dengan menyembelih seekor kerbau sebagai denda dan sekaligus sanksi bagi orang yang melakukan perkawinan rompak tutur ini. Bukan itu saja, mereka juga masih menerima hukuman secara sosial dengan terkucilnya mereka dari kehidupan masyarakat adat. Biasanya mereka yang melakukan perkawinan semarga atau mengawini anak perempuan dari saudara perempuan ayah (bou) pergi merantau agar perasaan terhukum itu dapat dihilangkan. ${ }^{23}$

Sistem perkawinan di Tapanuli Selatan adalah eksogami. ${ }^{24}$ Sistem ini mengharuskan

nasi, kepala kambing yang sudah dimasak dan dibumbui, telur ayam yang sudah direbus, garam, paha kambing dan paha ayam, ikan sungai. Pangupa itu ditutup dengan daun pisang, kemudian ditutup dengan kain berwarna hitam.

${ }^{20}$ L.P. Hasibuan, Pangupa: Buku Nenek Moyang Masyarakat Tapanuli Selatan, h. 4.

${ }^{21}$ Rukiah Siregar, Pelajaran Adat Tapanuli Selatan: Bona-Bona ni Partuturon (Medan: t.p., 1979), h. 66.

${ }^{22}$ Syamsul Bahri Ritonga, "Roppak Tutur Menurut Adat Angkola Sipirok," dalam Media Forkala Ed. 4 Tahun II 04 (Medan: Forkala Sumut), h. 84-88. Raja Pamusuk di Desa Purbasinomba Kecamatan Padang Bolak Kabupaten Padang Lawas Utara, 7 April 2018.

${ }^{23}$ E.St. Harahap, Perihal Bangsa Batak (Jakarta: Bagian Bahasa Djawatan Kebudajaan, 1960), h. 104-105.

${ }^{24}$ H.M.D. Harahap, Adat Istiadat Tapanuli Selatan (Jakarta: Grafindo Utama, 1987), h. 47. 
seorang calon suami mencari calon isteri dari luar marganya atau di luar sukunya. Misalnya seorang laki-laki bermarga Harahap harus mencari calon isterinya di luar marga Harahap, seperti Siregar, Lubis, Nasution, Hasibuan dan sebagainya.

Pasca perkawinan, isteri harus bertempat tinggal di tempat suaminya atau di tempat keluarga suaminya. Dengan demikian, isteri tidak boleh tinggal bersama ibunya setelah kawin dan ia harus pindah ke rumah suaminya. Akibat perkawinan ini terbentuklan hubungan adat antara keluarga isteri dengan keluarga suaminya, yaitu mora (keluarga isteri) dan anak boru (keluarga suami). ${ }^{25}$ Meskipun demikian, adakalanya istri dan suaminya tetap tinggal di rumah isteri dengan beberapa situasi antara lain. Pertama, suami tidak sanggup membayar maskawinnya, lalu diputuskan dibayar dengan tenaga sehingga pengantin harus menetap di desa keluarga perempuan. Hal ini disebut dengan sonduk hela, matrilokal atau uxonilokal. Kedua, isteri adalah anak tunggal sehingga suami dibutuhkan untuk menjaga dan memelihara kedua orang tua dan semua harta benda milik orang tua isteri. Ketiga, isteri tidak memiliki saudara laki-laki sehingga tenaga suami diperlukan untuk menjaga orang tua dan harta bendanya.

Dalam masyarakat Tapanuli Selatan dikenal beberapa bentuk perkawinan dilihat dari cara keberangkatan pengantin perempuan dari rumah orang tuanya. Pertama, boru na dipabuat. Artinya, pemberangkatan seorang boru ke rumah calon suaminya yang dilaksanakan secara adat. Artinya seluruh kerabat, harajaon, hatobangon, dan dongan sahuta mengetahui dan mengambil bagian dalam upacara adat itu. Kedua, boru tangko binoto. Artinya keberangkatan seorang boru ke rumah calon suaminya hanya diketahui oleh orang tuanya dan satu dua keluarga yang amat dekat. Keberangkatan ini belum diberitahukan kepada kaum kerabat, hatobangon, harajaon, dongan sahuta, karena berbagai hal antara lain keberangkatan itu kurang direstui orang tua karena masalah biaya atau karena melanggar adat. Ketiga, boru na marlojong, yaitu boru yang kawin lari dengan pemuda pilihannya. Hal ini terjadi karena orangtua mereka sama sekali tidak merestui pernikahan itu. Larangan pernikahan itu dapat terjadi dari kedua belah pihak orang tua atau oleh orangtua pemuda saja atau oleh orang tua gadis saja. Tetapi pada umumnya larangan itu berasal dari pihak orang tua gadis itu. Keempat, boru na pagincatkon adalah boru yang kawin dengan seorang duda yaitu suami dari mendiang kakaknya. Boru ini menggantikan kakaknya. Yang biasanya terjadi apabila ada anak-anak kecil dari mendiang kakaknya itu agar perawatan anak-anak itu lebih terjamin jika dibandingkan dengan kalau beribu tiri. Kelima, boru na manginte bondul adalah seorang janda yang ditinggal mati suaminya menikah dengan abang atau adik mendiang suaminya. Perkawinan serupa ini hampir sama dengan boru na pagincatkon yaitu untuk menjamin perawatan anak-anak yatim. Keenam, boru na manaek atau dikenal juga dengan istilah boru na manyompo. Dalam hal ini seorang perempuan atas inisiatif sendiri datang ke rumah seorang laki-laki untuk minta dinikahi secara resmi. Tindakan perempuan ini terjadi karena beberapa hal, antara lain menuntut pertanggungjawaban

${ }^{25}$ Ibid., h. 46. 
laki-laki itu atas perbuatan zina yang mereka lakukan. Ketujuh, porda dumpang yaitu terjadi apabila seorang janda tidak menikah dengan abang atau adik kandung mendiang suaminya, tetapi dengan orang di luar kerabat suaminya.

\section{Hasil dan Pembahasan}

\section{Mainstream Perkawinan di Tapanuli Selatan: Sebuah Polarisasi}

Perkawinan di Tapanuli Selatan terpolarisasi ke dalam empat bentuk, yaitu perkawinan dengan cara hukum adat, perkawinan dengan cara oleh hukum Islam, perkawinan dengan cara hukum negara, dan perkawinan dengan pluralisme hukum. Keempat polarisasi ini dengan mudah ditemui dalam kehidupan masyarakat Tapanuli Selatan.

Perkawinan bentuk pertama adalah perkawinan dengan cara hukum adat. Perkawinan bentuk demikian lebih sering dikenal dengan istilah perkawinan maradat. Artinya perkawinan yang dilangsungkan dengan tata cara dan ketentuan menurut adat. Pada masyarakat Tapanuli Selatan, dikenal dua macam adat dilihat dari adat menek dan adat godang. Adat menek yang berarti adat kecil adalah pesta kecil di mana pesta perkawinan dengan menyembelih kambing atau ayam sebagai lahanan (landasan/sembelihan). Sedangkan adat godang atau yang berarti adat besar adalah pesta perkawinan yang menyembelih kerbau sebagai lahanannya. Menyembelih kerbau merupakan acara adat tertinggi dalam adat Tapanuli Selatan. Tidak ada lagi acara besar dan agung yang melebihinya. Dengan demikian, perbedaan adat menek dan adat godang adalah lahanannya. Lahanan dalam adat Tapanuli Selatan adalah ayam, kambing dan kerbau. Lahanan tersebut berfungsi menandakan besar kecilnya pesta perkawinan. Selain itu, lahanan ini memiliki implikasi hukum. Pertama, dalam adat menek tidak diperkenankan ada acara margondang dalam pesta perkawinan tersebut. Kedua, dalam adat menek tidak diperkenankan memakai pakaian atau baju adat Tapanuli Selatan di luar rumah. Ketiga, dalam adat menek tidak diperkenankan memakai ulos Batak. Keempat, dalam adat menek tidak dibolehkan memasang atribut-atribut adat seperti bendera-bendera adat. Kelima, dalam adat menek gelar adat yang bisa diberikan kepada pengantin laki-laki adalah mangaraja atau kali atau ja atau mara. Sementara dalam horja godang, pengantin laki-laki bisa diberikan gelar adat yaitu sutan atau tongku atau baginda. ${ }^{26}$

Hukum adat mengenai perkawinan di Tapanuli Selatan memiliki dinamika unik. Keunikan tersebut terdapat dalam beberapa aspek seperti ketentuan siapa yang boleh dan tidak boleh mengadakan adat godang. Secara umum, orang yang memiliki kemampuan finansial yang kuat dibolehkan mengadakan adat godang dengan menyembelih kerbau dan margondang. Ketentuan ini berlaku di daerah Kota Padangsidimpuan, Kabupaten.

${ }^{26}$ Wawancara dengan Porkas Dalimunthe BA Gelar Patuan Kumala Suangkupon Dalimunthe, Raja di Desa Muaratais Kecamatan Batang Angkola Kabupaten Tapanuli Selatan, 18 Mei 2018. 
Namun di daerah Mandailing Natal, adat godang hanya bisa dilakukan oleh orang yang memiliki "garis". Maksudnya adalah orang yang memiliki keturunan raja. Ini artinya hanya keturunan raja yang bisa mengadakan adat godang. Orang yang tidak memiliki "garis" keturunan raja tidak berhak mengadakan adat godang. ${ }^{27}$ Selain itu, ada kalangan tertentu dalam masyarakat yang tidak bisa mengadakan adat godang menurut perspektif adat, yaitu orang yang tidak maradat ketika kawin. Artinya, jika ia tidak maradat ketika menikah, maka anaknya kelak juga tidak bisa maradat ketika akan menikah. ${ }^{28}$ Keunikan lain adalah tradisi minum "cuka" pada saat pesta perkawinan. Cuka adalah air enau atau air kelapa yang diendapkan dan dicampur dengan akar pohon yang disebut "raru" yang akan mengalami fermentasi dan menghasilkan minuman yang membuat peminumnya mabuk. ${ }^{29}$ Kebiasaan ini dijumpai di daerah Kabupaten Padang Lawas Utara.

Dominasi adat sangat kuat dalam perkawinan bentuk pertama ini. Terutama dalam perkawinan dengan adat godang yang disertai dengan acara manortor. Pesta dilakukan dua sampai tiga hari dengan biaya yang sangat besar, yaitu sekitar Rp. 50.000.000,- hingga Rp.150.000.000,-. Meskipun menghabiskan biaya besar, tidak sedikit orang yang memiliki ekonomi lemah mengadakan acara maradat tersebut. Bahkan tidak jarang ada orang yang menjual barang benda miliknya seperti tanah dan sawah untuk mengadakan adat godang tersebut. Hal dilakukan karena mereka memandang bahwa mengadakan adat godang untuk mengawinkan anak laki-lakinya adalah hutang adat yang menjadi kewajiban atas dirinya. Jadi, semua upaya dilakukan sekalipun harus menjual harta miliknya demi melunasi hutang adat tersebut. ${ }^{30}$

Bentuk kedua adalah perkawinan dengan cara hukum Islam. Dalam masyarakat Tapanuli Selatan, perkawinan bentuk ini dikenal dengan perkawinan marjamu. Bentuk perkawinan ini sangat kontradiktif dengan perkawinan bentuk yang pertama, yaitu maradat. Jika dalam perkawinan maradat nuansa adat sangat kental, pada perkawinan marjamu tidak ditemukan acara adat. Perkawinan marjamu kental dengan nuansa agama, di mana perkawinan dilaksanakan sesuai ketentuan hukum Islam. Perkawinan bentuk ini terutama diadakan oleh kalangan masyarakat yang memiliki tingkat religiusitas yang tinggi. Mereka bukan antipati terhadap adat, akan tetapi mereka memandang bahwa perkawinan dengan

${ }^{27}$ Wawancara dengan Sahyuddin Nasution Gelar Tuan Mangaraja Sian Nasution, Raja di Mandailing. Tinggal di Desa Panyabungan Tonga Kecamatan Panyabugan Kota Kabupaten Mandailing Natal, 18 April 2018.

${ }^{28}$ Wawancara dengan Hasbulla Harahap Gelar Sutan Maujalo Harahap. Beliau adalah Raja Pamusuk di Desa Purbasinomba Kecamatan Padang Bolak Kabupaten Padang Lawas Utara, 7 April 2018.

${ }^{29}$ Wawancara dengan Pangadilan Siregar, masyarakat Desa Binanga Kecamatan Barumun Kabupaten Padang Lawas, 9 Juni 2018.

${ }^{30}$ Wawancara dengan Mansyuruddin Hasibuan Gelar Baginda Sutan Kali Hasibuan, Raja di Kecamatan Binanga Kabupaten Padang Lawas, 12 April 2018. 
maradat cenderung bertentangan dengan hukum Islam. ${ }^{31}$ Perkawinan dalam bentuk yang kedua ini banyak dijumpai di Kota Padangsidimpuan dan Kabupaten Mandailing Natal dan Kabupaten Padang Lawas.

Bentuk perkawinan ketiga adalah perkawinan yang dilaksanakan dengan aturan hukum negara. Pada umumnya, masyarakat Tapanuli Selatan tunduk dan patuh terhadap aturan dan hukum negara dalam perkawinan, terutama dalam hal pencatatan perkawinan. Mayoritas perkawinan di Tapanuli Selatan terdaftar di kantor Urusan Agama. ${ }^{32}$ Masyarakat Tapanuli Selatan memiliki kesadaran hukum yang baik dalam pencatatan perkawinan. Mereka memahami dampak positif dari pencatatan perkawinan dan dampak negatif dari perkawinan yang tidak dicatatkan di Kantor Urusan Agama. Perkawinan yang tidak dicatatkan di Kantor Urusan Agama biasanya adalah perkawinan yang dilakukan dengan marlojong (kawin lari) dan kawin bagi yang hamil di luar nikah.

Bentuk perkawinan keempat adalah perkawinan dengan pluralitas hukum. Pada bentuk yang keempat ini, perkawinan dilaksanakan berdasarkan lebih dari satu sistem hukum yang ada. Pelaksanaannya bisa beberapa bentuk. Pertama, perkawinan dengan tunduk pada hukum Islam dan hukum negara. Kedua, perkawinan dengan tunduk pada hukum adat dan hukum negara. Ketiga, perkawinan dengan tunduk pada hukum Islam dan hukum adat. Keempat, perkawinan dengan tunduk pada hukum adat, hukum Islam dan hukum negara sekaligus.

\section{Pluralisme Hukum Perkawinan di Tapanuli Selatan: Ketegangan atau Harmonisasi?}

Pluralisme hukum perkawinan di Tapanuli Selatan adalah representasi dari relasi antar hukum yang harmonis yang dalam istilah Griffiths disebut strong legal pluralism. Bukti yang dapat dikemukakan adalah bahwa pada umumnya pelaksanaan perkawinan di Tapanuli Selatan menggunakan dua sistem hukum bahkan lebih. Satu di antaranya adalah hukum agama, dalam hal ini agama Islam sebagai agama mayoritas mereka. ${ }^{33}$ Semua

${ }^{31}$ Wawancara dengan Akhtar Harahap, Tokoh adat di Desa Purbasinomba Kecamatan Padangbolak Kabupaten Padang Lawas Utara, 19 Juni 2018.

${ }^{32}$ Wawancara dengan Hamdan Siregar, S.Ag., Kepala Kantor Urusan Agama Kecamatan Sipirok Kabupaten Tapanuli Selatan, 25 Agustus 2018.

${ }^{33}$ Dari aspek organisasi, orang-orang Mandailing berkiprah di sejumlah organisasi Islam. Ulama-ulama Mandailing bahkan mendirikan Al Washliyah di Medan, Sumatera Timur, kemudian Nahdlatul Ulama di Tapanuli. Beberapa tokoh dari etnik Mandailing berkiprah di Muhammadiyah dan Al-Ittihadiyah. Lihat Mhd. Syahnan, "Nahdlatul Ulama Scholar in Mandailing Land: A Biography of Shaykh Ali Hasan Ahmad ad-Dary," dalam Journal of Contemporary Islam and Muslim Societies, Vol. 3 No. 1, 2019; Salamuddin Salamuddin, "Meneguhkan Islam Nusantara: Nahdlatul Ulama dan Falsafah Pendidikan Pesantren Musthafawiyah," dalam Journal of Contemporary Islam and Muslim Societies, Vol. 3 No. 1, 2019; Soiman Soiman, "Gerakan Pembaruan Pendidikan 
perkawinan orang Islam dilakukan dengan mengikuti aturan hukum Islam, terutama dalam hal akad nikah. Masyarakat Tapanuli Selatan memiliki kesadaran yang baik tentang akad nikah ini. Mereka memahami urgensi akad nikah dalam perkawinan dengan baik, yaitu sebagai legalitas atau keabsahan perkawinan.

Terdapat beberapa pilihan hukum bagi masyarakat Tapanuli Selatan paska akad nikah menurut ketentuan hukum Islam, yaitu hukum negara dengan mencatatkan perkawinan dan atau hukum adat dengan cara maradat atau dengan menggabungkan ketiga sistem hukum tersebut. Jika pilihan hukumnya adalah hukum Islam dan hukum negara, maka hukum adat diabaikan. Kondisi ini tidak mengindikasikan dominasi hukum Islam dan hukum negara atas hukum adat, akan tetapi sebagai bentuk relasi yang harmonis. Para tokoh adat tidak keberatan jika perkawinan dilaksanakan dengan hukum Islam dan negara tanpa adat. Sebaliknya jika perkawinan dilaksanakan dengan tunduk pada hukum adat, maka tokoh agama tidak keberatan.

Bentuk harmonisasi dari relasi antar hukum terutama hukum Islam dan hukum adat adalah tercermin dalam jargon "hombardo adat dohot ibadat". Kalimat ini berarti "adat bergandengan dengan agama/ibadah". Jargon ini lahir sebagai hasil dari perjalanan panjang keduanya. Beberapa dekade yang lalu, keduanya berada pada posisi saling bertentangan. Jika perkawinan dilaksanakan dengan cara Islam, maka tokoh adat tidak berkenan menghadirinya. Begitu pula sebaliknya, jika perkawinan dilaksanakan dengan cara adat, maka tokoh agama tidak menghadirinya. Namun, pada perkembangan selanjutnya ada tokoh adat yang mendalami agama Islam dan menunaikan haji sehingga pada akhirnya ia dikenal dengan tokoh adat sekaligus tokoh agama. Atau sebaliknya ada tokoh agama yang tertarik untuk mendalami adat.

Selain harmonisasi hukum, ketegangan antar hukum juga terjadi meskipun dalam skala yang kecil. Misalnya ketentuan mengenai orang-orang yang haram atau tidak boleh dinikahi. Hukum Islam menentukan orang-orang yang haram dinikahi sesuai dengan konsep fiqh al-munâkahat. Sementara hukum adat juga menentukan orang yang tidak boleh dinikahi seperti pernikahan semarga. Ketegangan muncul ketika ada seorang laki-laki Muslim hendak menikah dengan wanita Muslim dan keduanya memiliki marga yang sama. Mereka dihadapkan pada dua hukum yang sama-sama mereka anut. Situasi dilematis seperti ini biasanya berujung pada dua alternatif, membatalkan atau meneruskan perkawinan meskipun tanpa izin dari orangtua.

Al Ittihadiyah di Sumatera Timur, 1935-1975," dalam Journal of Contemporary Islam and Muslim Societies, Vol. 2 No. 2, 2018; Dja'far Siddik, "Dinamika Organisasi Muhammadiyah di Sumatera Utara," dalam Journal of Contemporary Islam and Muslim Societies, Vol. 1, No. 1, 2017; Jafar Jafar, "Al Jam'iyatul Washliyah dan Problem Kepemimpinan Non Muslim dan Perempuan," dalam Ahkam: Jurnal Ilmu Syariah, Vol. 17, No. 2, 2017; Ja'far Ja'far, "Respons Al Jam'iyatul Washliyah Terhadap Terorisme," dalam Akademika: Jurnal Pemikiran Islam, Vol. 22, No. 1, 2017. 


\section{Penutup}

Masyarakat Tapanuli Selatan menghimpun tiga bentuk hukum dalam perkawinan, yaitu hukum adat, hukum positif dan hukum Islam. Ketiganya dilaksanakan secara berkelindan dan menyatu, sehingga legalitas perkawinan diakui oleh ketiga hukum tersebut. Pluralisme hukum yang terjadi di Tapanuli Selatan Provinsi Sumatera Utara dalam bidang perkawinan adalah representasi dari berjalannya berbagai sistem hukum secara beriringan pada saat yang bersamaan. Masyarakat tidak mempertentangkan antar hukum, akan tetapi mereka menyandingkan dan menempatkan hukum-hukum yang ada secara proporsional. Keragaman hukum adalah sebuah harmoni bagi mereka. Di Tapanuli Selatan, hukum adat, hukum Islam dan hukum positif bekerja atau "beroperasi" sesuai dengan fungsinya tanpa ada "ketegangan" yang berarti. Dengan demikian penelitian ini mendukung pandangan John Griffths tentang strong legal pluralism.

\section{Pustaka Acuan}

Beckmann, Franz Benda \& Keebet von Benda-Beckmannn. "Changing One is Changing All: Dynamics in the Adat-Islam-State Triangle," dalam The Journal of Legal Pluralism and Unofficial Law, Vol. 38, 2006.

Beckmann, Keebet von Benda dan Bertram Turner. "Legal Pluralism, Social Theory, and the State," dalam The Journal of Legal Pluralism and Unofficial Law, Vol. 50, No. 3, 2018.

Birgit, Brauchler. "The Revival Dilemma: Reflections on Human Rights, Self-Determination and Legal Pluralism in Eastern Indonesia," dalam The Journal of Legal Pluralism and Unofficial Law, Vol. 42, 2010.

Ehrlich, Eugen. Fundamental Principles of the Sociology of Law. Walter L. Moll trans, 1936.

Harahap, E.St. Perihal Bangsa Batak. Jakarta: Bagian Bahasa Djawatan Kebudajaan, 1960.

Harahap, H.M.D. Adat Istiadat Tapanuli Selatan. Jakarta: Grafindo Utama, 1987.

Hasibuan, L.P. Pangupa: Buku Nenek Moyang Masyarakat Tapanuli Selatan. Medan: Mitraco, 1991.

Holden, Livia \& Azam Chaudhary. "Daughters' Inheritance, Legal Pluralism, and Governance in Pakistan," dalam The Journal of Legal Pluralism and Unofficial Law, Vol. 45, 2013.

Ja'far, Ja'far. "Respons Al Jam'iyatul Washliyah Terhadap Terorisme," dalam Akademika: Jurnal Pemikiran Islam, Vol. 22, No. 1, 2017.

Jafar, Jafar. "Al Jam'iyatul Washliyah dan Problem Kepemimpinan Non Muslim dan Perempuan," dalam Ahkam: Jurnal Ilmu Syariah, Vol. 17, No. 2, 2017.

John, Griffiths. "What is Legal Pluralism?," dalam The Journal of Legal Pluralism and Unofficial Law, Vol. 18, 1986. 
Kirchmair, Lando. "Descriptive vs. Prescriptive Global Legal Pluralism: A Gentle Reminder of David Hume's is-Ought Divide," dalam The Journal of Legal Pluralism and Unofficial Law, Vol. 51, 2019.

Kleinhans, Martha-Marie dan Roderick A Macdonald. "What is a Critical Legal Pluralism," dalam Canadian Journal of Law and Society, Vol. 12 No. 2, 1997.

Merry, Sally Engle. "Legal Pluralism," dalam Law and Society Review, Vol. 22, No. 11988.

Miharja, Deni. "Persentuhan Agama Islam dengan Kebudayaan Asli Indonesia," dalam MIQOT: Jurnal Ilmu-Ilmu Keislaman, Vol. XXXVIII, No. 1, 2014.

Murdan. "Pluralisme Hukum (Adat dan Islam) di Indonesia," dalam Mahkama: Jurnal Kajian Hukum Islam, Vol. 1 No. 1, Juni 2016.

Ritonga, Syamsul Bahri. "Roppak Tutur Menurut Adat Angkola Sipirok," dalam Media Forkala, Ed. 4 Tahun II 04. Medan: Forkala Sumut.

Salamuddin, Salamuddin. "Meneguhkan Islam Nusantara: Nahdlatul Ulama dan Falsafah Pendidikan Pesantren Musthafawiyah," dalam Journal of Contemporary Islam and Muslim Societies, Vol. 3 No. 1, 2019.

Salim, Arskal. "Contemporary Islamic Law in Indonesia: Sharia and Legal Pluralism," The Aga Khan University, Vol. 6, 2015.

Sbriccoli, Tommaso. "Legal Pluralism In Discourse: Justice, Politics And Marginality In Rural Rajasthan, India”, dalam The Journal of Legal Pluralism and Unofficial Law, Vol. 45, 2013.

Siddik, Dja'far. "Dinamika Organisasi Muhammadiyah di Sumatera Utara," dalam Journal of Contemporary Islam and Muslim Societies, Vol. 1, No. 1, 2017.

Siregar, Rukiah. Pelajaran Adat Tapanuli Selatan: Bona-Bona ni Partuturon. Medan: 1979.

Soiman, Soiman. "Gerakan Pembaruan Pendidikan Al Ittihadiyah di Sumatera Timur, 1935-1975," dalam Journal of Contemporary Islam and Muslim Societies, Vol. 2 No. $2,2018$.

Swenson, Geoffrey. "Legal Pluralism in Theory and Practice," dalam International Studies Review, Vol. 20, 2018.

Syahnan, Mhd. Contemporary Islamic Legal Discourse. Medan: IAIN Press, 2010.

Syahnan, Mhd. Hukum Islam dalam Bingkai Transdisipliner. Medan: Perdana Publishing, 2018.

Syahnan, Mhd. Modernization of Islamic Law of Contract. Jakarta: Badan Litbang \& Diklat Departemen Agama RI, 2009.

Syahnan, Mhd. "Nahdlatul Ulama Scholar in Mandailing Land: A Biography of Shaykh Ali Hasan Ahmad ad-Dary," dalam Journal of Contemporary Islam and Muslim Societies, Vol. 3 No. 1, 2019.

Tamahana, Brian Z. "Understanding Legal Pluralism: Past to Present, Local to Global," dalam Sydney Law Review, Vol. 30, 2007. 
MIQOT Vol. 43 No. 1 Januari-Juni 2019

Urinboyev, Rustamjon \& Mans Svensson. "Living Law, Legal Pluralism, and Corruption in Post-Soviet Uzbekistan," dalam The Journal of Legal Pluralism and Unofficial Law, Vol. 45, 2013.

Zaki, M. "Arah Legislasi Hukum Islam di Indonesia dalam Perspektif Interaksi Agama dan Negara," dalam MIQOT: Jurnal Ilmu-Ilmu Keislaman, Vol. XLII, No.2, 2015. 